\title{
The Elementary School Teacher, the Thug and his Grandmother: Informal Brokers and Transnational Migration from Indonesia ${ }^{1}$
}

\author{
Johan Lindquist
}

\begin{abstract}
This article considers the emergence of informal brokers in the context of an increasingly formalized regime of transnational labour migration from Indonesia. Following the 1997 Asian economic crisis and the fall of the Suharto regime, there has been a dramatic increase in documented transnational migration to Malaysia at the expense of undocumented migration. In this process, a growing number of private agencies have come to control the increasingly deregulated market for migrant recruitment. These agencies, in turn, depend on informal brokers who recruit migrants in villages across Indonesia to work on palm oil plantations and as domestic servants in countries such as Malaysia and Saudi Arabia. This article takes these informal brokers as a starting point for considering the current Indonesian migration regime, using ethnographic data from the island of Lombok. Along with offering a description of brokering practices, the article argues that the dual process of centralization of migration control and fragmentation of labour recruitment has created a space of mediation for individuals who can navigate bureaucratic process while embodying the ethical qualities that convince Indonesian villagers to become migrants.
\end{abstract}

KEYWORDS: Indonesia, Malaysia, Saudi Arabia, migration, brokers, labour recruitment

DOI: http:/ /dx.doi.org/10.5509/201285169

\footnotetext{
1 This article is a continuation of a previous publication that dealt with private recruitment agencies: "Labour Recruitment, Circuits of Capital and Gendered Mobility: Reconceptualizing the Indonesian Migration Industry," Pacific Affairs 83, no. 1 (2010): 115132. Thanks to comments from participants in the workshop, "Opening the Black Box of Migration: Brokers and the Organization of Transnational Mobility," at the Asia Research Institute, National University of Singapore, 19-20 August 2010, in which I presented a first version of this essay. Thanks also to Hyung Gu Lynn and the staff at Pacific Affairs for their support, and to Staffan Löfving and the three anonymous reviewers for helpful comments on an earlier draft.
} 
$\mathrm{I}$

$\mathrm{t}$ is almost maghrib, the time for the Muslim evening prayer, as we make our way along the two-lane highway that connects eastern and western Lombok, an island approximately 4700 square kilometres in size with around three million inhabitants, located just east of Bali in Indonesia. Ibrahim, the manager of Nusa, a private labour recruitment agency that sends migrants to work on Malaysian palm oil plantations, and Adi, his assistant, are in the front of the SUV smoking clove cigarettes and listening to Jakarta pop music, which expresses their unspoken lament. Both have been sent from the main office in the capital, and neither speaks the local Sasak language. I am in the back seat with Pak Haji Ismael, a local elementary-school teacher of religion who moonlights as a petugas lapangan, or "field agent," and handles the actual recruitment of migrants for Nusa and other agencies.

We are returning from a meeting held at the house of Pak Haji's sonin-law, a police officer in East Lombok who has used his local connections to organize a meeting for about twenty prospective migrants. The sonin-law is one of a half-dozen sub-brokers that he uses in the recruitment process. At the event, Pak Haji acted as the host and led the opening Muslim prayer before introducing the guests from Nusa, who handed out brochures and talked about the company and the various work contracts they were currently offering in Malaysia. His son-in-law rushed in and out of the living room carrying snacks and water as the discussion progressed, while the guests, in typical fashion, sat in a circle on the floor. Although most of the prospective migrants had been to Malaysia several times before, both as undocumented and documented workers, and had questions about the specific plantations Nusa was supplying as well as the range of salaries—rather than the nature of the labour itself-neither Pak Haji, Adi nor Ibrahim have ever been to Malaysia themselves. Despite this, most of the men, several of whom spoke a distinctive (and apparently selfconscious) Malay dialect, seemed satisfied with the meeting and willing to use Pak Haji as their broker and Nusa as their agency.

Back in the car, Pak Haji is pleased-I can tell from the way he strokes his string of beads-and he tells us he plans to visit each of the men the following week. He is particularly happy that they all claim to be able to access the four million rupiah (about US $\$ 400$ ) that they have to pay for a two-year contract on a Malaysian palm oil plantation. Lack of access to capital is usually the main hindrance for male migrant departures, although money lenders, often charging 100 percent interest, are widely available. Women, in contrast, who have increasingly migrated to become domestic servants during the last decade, rarely have to pay prior to departure. But Pak Haji avoids recruiting women, not because he feels they should not leave home on their own, but because there is too great a risk that they will experience abuse or become pregnant abroad, and that he will be held accountable by family members as a result. 
This is the first time that Pak Haji has recruited migrants for Nusa. $\mathrm{He}$ is well known across the island as a successful broker who delivers what he promises. For this reason Nusa has been courting him for quite some time, and have now sent out their local manager to support him in the initial stages, something they generally only do for their most important brokers. For Pak Haji, this is a welcome move since he has had problems with another agency that delivered migrants to a different Malaysian plantation than promised. A couple of migrants had returned to Lombok before the end of their contracts-disappointed by the low salaries-and had demanded their money back. In order to retain his reputation, he felt compelled to comply.

As we drive back towards his house in central Lombok, Pak Haji asks Ibrahim a series of questions about Nusa, leaving the critical question for last: "Berapa setoran?" or, "How much is the deposit?" Ibrahim, who has been expecting the question, answers: "two three," short for 2.3 million rupiah, or US\$230. This means that from the four million the migrant pays Pak Haji, the agency gets 2.3 and he receives a gross sum of 1.7 million. Deducted from this are a series of costs: compulsory government documents, most notably the passport, payments to sub-brokers such as his son-in-law, gasoline, food, and cell phone credit. In the back seat I can see how Pak Haji nods his head forward, again pleased, since 2.3 million is slightly below the market price that agencies charge, allowing him to pocket the difference from the departing migrant. As we move along slowly behind a line of cattle trucks, he suddenly asks Adi to pull over. It is time to pray. We stop at the side of road, and the three men get out of the car, leaving me behind to contemplate the day's events. ${ }^{2}$

\section{The Rise of the Broker}

The petugas lapangan, or PL for short, also sometimes called sponsor, has become a critical figure in Indonesian transnational labour recruitment since the 1997 Asian economic crisis, replacing the tai kong, the migrant smuggler, who was at the centre of undocumented labour migration to Malaysia until the 1990s. ${ }^{3}$ The crisis was a watershed for Indonesian migration to Malaysia, in particular, with recurring deportation

\footnotetext{
$2 \quad$ During one longer and three shorter visits between 2007 and 2010 I have conducted nearly six months of fieldwork on Lombok. Most of this research has focused explicitly on recruitment agencies and informal brokers, rather than migrants. In this process, I have spent most of my time interviewing and observing everyday life in recruitment agencies and government offices, and driving around the island to visit informal brokers. I expect that the project will be developed in comparative terms, as I hope to begin fieldwork in the largely Christian parts of Flores-located east of Lombok-in 2012.

Although the World Bank states in a recent report that migrant flows to Malaysia are primarily undocumented (see Raúl Hernández-Coss, Gillian Brown, Chitawati Buchori, Isaku Endo, Emiko Todoroki, Tita Naovalitha, Wameek Noor and Cynthia Mar, "The Malaysia-
} 
campaigns and the creation of a state-sponsored civil volunteer corps with the right to detain undocumented migrants in exchange for cash rewards. ${ }^{4}$ In the wake of these processes, a faciliated work visa process and Memorandums of Understanding (MOUs) between the Indonesian and Malaysian governments have aimed to regulate and protect the mobility of migrants between the countries. On Lombok, an important supplier of labour to Malaysian palm oil plantations, the changes of the past decade have led to a dramatic increase in documented migration, as the PL-competent in bureaucratic process-has superseded the tactical knowledge of the tai kong. Although the PL comes to work within a more constricted and legitimate space of "documented" migration, compared to that of the tai kong, both move along the boundary between "illegality" and "legality," particularly with regard to the small-scale corruption that is endemic in Indonesia. As such there are obvious historical continuities in the brokering of transnational migration. ${ }^{5}$

Indonesian documented migration has intensified after the 1997 crisis, most notably through the growing number of female domestic servants who have come to work for the expanding middle classes across Asia and the Middle East. In 2006, women accounted for 80 percent of all documented migration from Indonesia, with 88 percent working in the domestic sector, reflecting the ongoing feminization of labour migration in Southeast Asia. ${ }^{6}$ Widely publicized abuses against female domestic servants in Malaysia, Singapore and Saudi Arabia, in particular, have led to recurring temporary Indonesian government bans on the migration of domestic servants. ${ }^{7}$ The call for protection has reinforced the regulation of migration in Indonesia, for instance through the

Indonesia Remittance Corridor: Making Formal Transfers the Best Options for Women and Undocumented Migrants" (World Bank Working Paper no. 149, 2008), 57), my field research suggests that in recent years there has been a drop in undocumented and a rise in documented migration from Indonesia to Malaysia, particularly in the context of the exclusively male palm oil and construction industries. On Lombok, this shift has been particularly obvious. During field work it was nearly impossible to find brokers or migrants who were interested in sending or being sent to Malaysia without a passport. For further examples from West Java, see Olivia Killias, “'Illegal' Migration as Resistance: Legality, Morality and Coercion in Indonesian Domestic Worker Migration to Malaysia," Asian Journal of Social Science 38, no. 6 (2010): 897-914.

4 Christine Chin, “Diversification' and 'Privatisation': Securing Insecurities in the Receiving Country of Malaysia,” Asia Pacific Journal of Anthropology vol. 9, no. 4 (2008): 285-303.

$5 \quad$ For a historical perspective on Java, see Ernst Spaan, "Taikongs and Calos: The Role of Middlemen and Brokers in Javanese International Migration," International Migration Review 28, no. 1 (1994): 93-113. On the tai kong, see Sidney Jones, Making Money off Migrants: The Indonesian Exodus to Malaysia (Hong Kong: Asia 2000 Ltd, 2000).

Hernández-Coss et al., "The Malaysia-Indonesia Remittance Corridor," 8.

See, for instance, Nazeer, Zubaidah and Elizabeth Looi, "Muddle Over Maids: A Malaysian-Indonesia Dispute Over the Treatment of Maids is Hurting Both Sides," The Straits Times (Singapore), January 28, 2011. 
creation of special migrant airport terminals, first in Jakarta and later in a number of cities across the country, while leading to an increasing bureaucratization of the migration process. ${ }^{8}$

In Indonesia, the formalization of temporary labour migration has been matched by the deregulation of the labour recruitment market, which followed the dismantling of monopolies after the fall of the dictator Suharto in $1998 .{ }^{9}$ This has led to changes in the structure of transnational migration, primarily through the growth in private labour recruitment agencies. These PPTKIS (Perlaksana Penempatan Tenaga Kerja Indonesia Swasta, Private Placement Managers of Indonesian Workers) control the market for documented migration across the country, with the main destinations being Malaysia, mainly for male palm oil workers, and Saudi Arabia, particularly for female domestic workers. In 2010, there were more than 500 registered agencies of varying size and stability in Indonesia; with most having multiple branch offices across the country. ${ }^{10}$ It is not unreasonable to estimate that there may be several thousand labour recruitment offices in Indonesia. On Lombok alone there are over 150, six main offices and the rest branches.

Each of these agencies are in turn dependant on a large number of PL who work without contracts and are paid for each migrant they deliver. In fact, the success of any agency is directly connected to that of their PL. Nusa, one of the largest agencies on Lombok-delivering up to 3000 migrants per year-has nearly one hundred more-or-less regular PL who come from villages around the island. Rarely, however, do these recruiters deliver strictly to one agency, but they move between several, depending, for instance, on the desired destination of the migrant, how quickly the agency offers payment, and especially the date of migrant departure. If the prospective migrant is forced to wait, there is increasing risk that he will drop out, particularly if the PL has offered loans to start the process. As a result, the reputation of the PL may be seriously affected.

\footnotetext{
$8 \quad$ Rachel Silvey, "Unequal Borders: Indonesian Transnational Migrants at Immigration Control," Geopolitics 12 (2007): 265-279. For a study that highlights the common effects of regulation and protection, see Daromir Rudnyckj, "Technologies of Servitude: Governmentality and Indonesian Transnational Labor Migration," Anthropological Quarterly 77 , no. 3 (2004): 407-434.

For a similar process, see Xiang's article in this issue.

This can be compared to the nearly 1500 agencies registered in the Philippines in 2006. See Anna Guevarra, Marketing Dreams, Manfacturing Heroes: The Transnational Labor Brokering of Filipino Workers (New Brunswick: Rutgers University Press, 2010), 90. In the last decade there has been a steady rise of agencies in the Philippines. For instance, the number of agencies delivering migrants to the United Arab Emirates has more than doubled during this period. See Dovelyn Rannveig Agunias, "Migration's Middlemen: Regulating Recruitment Agencies in the Philippines-United Arab Emirates Corridor" (Washington, DC: Migration Policy Institute, 2010).
} 
As my tongue-in-cheek title suggests, there is an incredible variation among the PL I have encountered: they include not only former migrants and smugglers, but also travelling salesmen, university researchers, tourist guides, used car salesmen, land brokers and low-level state bureaucrats. In fact, there is a greater number and diversity of brokers during the contemporary era of the PL compared to that of the tai kong, not only because of increasing migration, but also as an effect of the increasing bureaucratization and legitimacy of the migration industry. A telling joke I heard on Lombok was that the best way to tell the difference between a migrant and a PL is that the latter carries a map, a folder with the various documents that the migrant needs in order to have a passport made. This diversity is reminiscent of a type of migrant labour broker widely vilified in North America more than one hundred years ago, namely the padrone, who could be found across a wide range of occupations, leading historian Robert Harney to define him as "a man whom other people call padrone." 11

The work of scholars such as Xiang on China (see this issue) and Rodriguez and Guevarra on the Philippines are showing how the international regulation of migration in Asia is developing together with a diverse market of private recruitment agencies that navigate processes of documentation and transport. ${ }^{12}$ These changes are often understood in relation to neoliberal reform-through the deregulation of markets, the sub-contracting of state activities to agencies, or the formation of a set of technologies that has a diverse series of effects on mobility and the migrants themselves. ${ }^{13}$ In fact, Rodriquez suggests that "labor brokerage might be a necessary insitutional form ... under conditions of neoliberal globalization." ${ }^{14}$ More broadly, the turn to documented migration can be conceptualized in relation to the dual processes of "roll-out" and "roll-back" neoliberalism, respectively, in which the centralization of migration control has been matched by the deregulation of the market for recruitment. ${ }^{15}$ Yet, while the private agency is generally understood as the key mediator in contemporary migrant recruitment, the importance of informal brokers in my Indonesian case suggests the need for more

\footnotetext{
11 See Robert Harney, "The Padrone and the Immigrant," Canadian Review of American Studies 5, no. 2 (1974), 110; and Gunther Peck, Reinventing Free Labor: Padrones and Immigrants in the North American West, 1880-1930 (Cambridge University Press, 2000), 18.

12 See Robyn Rodriquez, Migrants for Export: How the Philippine State Brokers Labor to the World (Minneapolis: University of Minnesota Press, 2010); and Guevarra, Marketing Dreams.

$13 \quad$ For instance, Rodriguez (2010) argues that the Philippines should be conceptualized as a labour brokerage state that is explicitly neoliberal.

$14 \quad$ Rodriguez, Migrants for Export, xxi-xxii.

15 See Jamie Peck and Adam Tickell, "Neoliberalizing Space," Antipode 34, no. 3 (2002), 380-404.
} 
carefully considering the social—rather than strictly political economicrelationships, which shape and make mobility possible. ${ }^{16}$

More specifically, I argue that the the dual process of centralization of migration control and fragmentation of labour recruitment has created a space of mediation not only for licensed private agencies but also for informal brokers who are able to navigate both bureaucratic process and market competition while embodying the ethical qualities that convince Indonesian villagers to become migrants. Following from this, there are several reasons why more explicit attention should be paid to informal brokers such as Pak Haji Ismael, who I introduced in the vignette above. First, it is the PL, rather than the state or private agency per se, who actually travels to villages around Indonesia to recruit migrants. If we want to understand how villagers become migrants it is critical to pay ethnographic attention to informal brokers and their practices. The issue of trust-meaning, most generally, "confidence in one's expectations"17_appears especially critical in environments where there are great cultural and economic divides between rural and urban spaces. PL such as Pak Haji thus come to function not only as labour recruiters but also as cultural brokers, as the one position is infused with the other. ${ }^{18}$ Second, by moving attention from state actors and private agencies to informal brokers, distinctions between "state" and "market," as well as "formal" and "informal," become increasingly difficult to sustain. In fact, as an elementary-school teacher, Pak Haji is actually a low-level bureaucrat and state official himself. Taking informal brokers as a starting point thus allows us to move beyond these dichotomies. Third, even if the current regime of international migration from Indonesia can be understood in terms of neoliberalization, in historical accounts of modern migration, as well as the colonial and post-colonial history of Indonesia, the figure of the broker has remained constantly in place, most notably vilified since the advent of liberalism and the "free" labourer. ${ }^{19}$ Taking the broker as a starting point, rather than an effect of an economic and political order, is thus a methodological strategy for engaging with neoliberalism more broadly. Finally, debates about transnational migration are widely framed in terms of dichotomies between "victims" and "perpetrators," with brokers generally inhabiting

\footnotetext{
16 The often-repeated call for studying "actually existing neoliberalisms" suggests as much (see Peck and Tickell, "Neoliberalizing Space," 383, for an early statement), but arguably the call has been repeated more often than actually generating a convincing response.

17 Niklas Luhmann, Trust and Power (Chichester: John Wiley, 1979), 4.

Clifford Geertz, "The Javanese Kijaji: The Changing Role of a Cultural Broker," Comparative Studies in Society and History 2, no. 2 (1960), 228-249.

19 See Adam McKeown's article in this issue, and his Melancholy Order: Asian Migration and the Globalization of Borders (New York: Columbia University Press, 2008).
} 
the latter position. The example of Pak Haji, however, problematizes this form of stereotyping and suggests that a deeper knowledge of the work of brokers allows us to complicate ethical discussions concerning transnational migration.

\section{From Villagers to Migrants}

I am on the back of Johri's motorcycle. It is early morning, July 2009, and we are headed away from the main city of Mataram along Lombok's east-west highway. Johri is a PL and we are on our way to visit one of his main sub-brokers, Rina, who has gathered a group of four women who are interested in travelling to Saudi Arabia as domestic servants. As we pass into Central Lombok, we are also gradually crossing the Wallace Line that divides the lusher and greener part of the island from the dryer and poorer areas to the east, which is the main source of migrant labour. Irrigated rice cultivation dominates the island's economy, but while there are often three harvests per year in the west, to the east there is generally only one. In recent years, other capital-intensive cash crops have become increasingly common; this is especially noticable in the east where rice fields are giving way to tobacco, which promises high profit margins for some but is easily destroyed by heavy rains. With tobacco, people say, one can either end up in Mecca or Malaysia, the former as a successful pilgrim, the latter as a destitute migrant.

The vast majority of Lombok's population is Muslim and the island is widely considered one of the most pious in Indonesia; it is frequently called "the island of a thousand mosques" and occasionally that of "a million thieves." Johri says as much when a few young men-the third such group within ten kilometres-appear in the middle of the road, shaking buckets to be filled with what are ostensibly mosque donations. The widespread usury that is at the heart of the migration industry merely serves to reinforce his point. As we cross into East Lombok, we turn north off the main road and slowly head uphill, dodging potholes along the way. Although the highway is in good repair, many villages located not more than 20 kilometres away are isolated and located outside of circuits of public transportation, as smaller roads leading north and south remain in a terrible state, particularly during the rainy season.

A few kilometres off the highway Johri's cell phone sounds and we pull over. It is Rina, one of his most important sub-brokers. PL never work alone. Like the vignette of Pak Haji that opened this article, Johri depends on an extensive network of sub-brokers who have direct access to migrants, most often because they are well known in the area where they recruit. Johri and Rina have been collaborating for more than two years, during which time she has recruited nearly 50 women for Johri from her own and neighbouring villages. Several potential migrants 
are already waiting in her house. He is keen to keep her happy since there are many other PL she could turn to, as well as the possibility of delivering directly to agencies herself once she has learned the tricks of the trade. Theirs is an inherently unstable relationship. "We'll be there in an hour," he tells her.

As in other parts of the country, the 1997 crisis signalled the beginning of a dramatic growth in documented migration flows from Lombok, where peasants depend primarily on temporary wage labour. ${ }^{20}$ One sign of the importance of contemporary migration is that remittances to West Nusa Tenggara province-of which Lombok and Sumbawa are the main islands-have quickly become greater than total local income. ${ }^{21}$ Prior to the crisis, most migrants were undocumented men on Malaysian palm oil plantations. Today, however, the majority are documented and pass through private recruitment agencies such as Nusa. Most notably, large numbers of young women, who, unlike men, do not have to pay recruitment fees prior to departure, are travelling abroad. Yearly departures to Saudi Arabia, for instance, increased by 15 times between 2004 and 2008. ${ }^{22}$ Moreover, the anti-Christian riots of 2000 on Lombok and the spill-over effect of the Bali bombs crippled a promising tourist industry, ${ }^{23}$ creating yet another group of workers who moved towards the rapidly expanding migration industry, either by becoming labour recruiters or migrants themselves, or both at the same time. Both Johri and Rina-as well as Pak Haji-have found a space for themselves in this new market of recruitment, one that they would not have engaged with as easily during the era of undocumented migration.

An hour and a half after the phone call, and sore from the increasingly bumpy ride, we pull up in front of Rina's house, apparently the largest in the area, and not more than a few years old; it is an example of the rumah Saudi, "Saudi houses," that are being built across the island with remittance money. Rina, who is in her early thirties, comes out to greet us and we are invited into the sitting room where the young women are waiting, all wearing jilbab, the Muslim headscarf. Rina was one of the first wave of women who left for Saudi Arabia in the late 1990s when her husband never returned from his own migration sojourn to Malaysia, transforming her into a Jamal, short for janda Malaysia, or Malaysian widow, a figure which has become prominent in Lombok's contemporary

20 John MacDougall, "Criminality and the Political Economy of Security in Lombok," in Hen Schulte Nordholt and Gerry van Klinken, eds., Renegotiating Boundaries: Local Politics in Post-Suharto Indonesia (Leiden: KITLV Press, 2007), 287.

$21 \quad$ Hernández-Coss et al., "The Malaysia-Indonesia Remittance Corridor, xiii.

22 BP3TKI Mataram, "BP3TKI Dalam Angka" (Mataram, Lombok, Balai Pelayanan Penempatan dan Perlindungan Tenaga Kerja Indonesia, 2009).

$23 \quad$ Leena Avonius, "Reforming Watu Telu: Islam, Adat, and the Promises of Regionalism in Post-New Order Lombok” (PhD thesis, University of Leiden, 2004). 
cultural vernacular. After several two-year contracts and enough money to build a new house, she remarried and turned to the far more lucrative business of labour recruitment. With her migration experience, material evidence of success, good standing, and easygoing manner, she is an ideal recruiter on the village level, but has limited contacts in Mataram. To be on the move between the city and the village could also negatively affect her local reputation as a woman and identify her more strongly as a broker connected to the outside world. In order to become a successful recruiter in her own social environment she needs not only to speak competently about the migration experience but also retain familiarity as a villager, thus creating a basis for trust. ${ }^{24}$

Johri first met Rina outside an agency where she was making inquiries about recruiting women migrants. She was there with a male relative from her village who was acquainted with Johri, and, in fact, a distant relative himself. Without a means of transportation, a knowledge of the intricacies of migration bureaucracy, and a lack of interest in engaging with the formal side of the migration process, Rina quickly agreed to collaborate with Johri, as she handled the recruitment of women in and around her village, and he dealt with the bulk of the documentation and the necessary transportation on Lombok and to Jakarta.

In contrast to confidence, trust entails a situation of risk..$^{25}$ The fact that Johri is known, but not well known, in Rina's village, is significant, since it points to the fact that PL prefer collaborating with acquaintances rather than close relatives. In other words, while there is some basis for trust, day-to-day social relationships are not threatened if collaboration fails, either because a migrant drops out after investments have been made, because one of the PL deceives the migrant or another PL, the agency fails to send the migrant, or the migrant experiences some kind of problem once abroad. All involved parties are well aware of the potential risks in each step of the migration process-and that these are impossible to control-but critically the decision to set the migration process in motion begins on the village level.

As we sit down and are served tea, Johri jokes about the bumpiness of the ride, something Westerners apparently are not used to. The women and I smile at each other. Johri is well dressed, with dark slacks, a white button-down shirt, and polished black shoes. He is more restrained than in our own conversations, but I am struck by how skillfully he creates rapport with the women through his charming style and discreet jokes.

\footnotetext{
$24 \quad$ On familiarity and trust, see Luhmann, Trust and Power, 33.

25 Niklas Luhmann, "Familiarity, Confidence, Trust: Problems and Alternatives," in Trust: Making and Breaking Cooperative Relations, ed. Diego Gambetta, electronic edition, Department of Sociology, University of Oxford, 2000, chapter 6, 94-107, http://www.sociology.ox.ac.uk/ papers/luhmann94-107.pdf, accessed on October 1, 2011.
} 
This is despite the fact that we are conversing in Indonesian rather than the local Sasak, in part because Johri speaks a different dialect, but also because I am there. After some further small talk, we soon turn to the migration process at hand. He explains that once the women have agreed to depart he will escort them to the Jakarta training centre of PT Timor Tengah, the agency he is recruiting for. There the women will learn basic Arabic, as well as other household and childcaring skills during a couple of months, before departing to Saudi Arabia. Johri talks more about what it is like to work as a domestic servant and Rina adds information from her own experience. Occasionally one of the other women will ask Rina something in Sasak rather than Indonesian, and she will respond. Johri nods each time, but does not intervene. The women all appear familiar with the process. Two of them are divorced with young children, while the third woman is unmarried and in her early twenties. Later Rina tells us that she is the oldest child from a very poor family. The fourth woman is yet another sub-broker-herself a recently returned migrant from Saudi Arabia—who has brought the unmarried woman to Rina.

After about half an hour, the women appear satisfied, and get up to leave. The sub-broker lags behind and asks Rina for some money. Rina turns to Johri who opens his wallet and gives the woman two hundred thousand rupiah, about US\$20. Once she leaves, Rina, Johri and I sit down together. All the women have medical certificates and letters of permission from their parents, and there do not seem to be any problems on the horizon. A key initial document is a signed letter of permission from the husband or father of the prospective female migrant (surat izin suami or keluarga), which generally entails the first interaction with and payment to a state bureaucrat since the letter is drafted and paid for in the office of the village head. In other words, the recruitment of women involves a broader array of social negotiations compared with that of men, where the main problem is accessing capital. Rina appears confident that all the women will be ready to depart within a couple of weeks. Johri says that he will have the agency book airline tickets to Jakarta in two weeks time.

In the recruitment process Rina has handed out "shopping money" to the women and their parents, and some further money to the village head to draw up and sign the letter of permission. Two women who were supposed to meet with Johri have dropped out despite the fact that Rina had already given them shopping money. Apparently, one of them had decided to go with another PL, while the second woman had just decided against leaving. This had caused Rina some stres since she had not been able to retrieve the money. Johri nods and once again reaches into his wallet for a million rupiah, about US\$100. Rina appears disappointed, but he promises more the next time they meet. Later he explains that he has to find a balance between offering money in advance and 
waiting until he is certain that the migrants will depart. As we get on the motorcycle, his cell phone rings again. It is one of his other sub-brokers, who lives a further hour to the east.

Johri is originally from Central Lombok. He lived in Jakarta for several years during the migration boom following the 1997 crisis and came to work for a transportation company that drove migrants back home to Lombok and Sumbawa upon arrival at Soekarno-Hatta Airport's designated migrant terminal. Since the company also owned a middle-sized private recruitment agency, PT Timor Tengah, which sends migrants to Saudi Arabia, Johri came to learn a great deal about the general structure of the migration industry and realized that working as a PL in the provinces was his best possibility of moving ahead as the number of migrant women to Suadi Arabia exploded. PT Timor Tengah, which had a branch office on Lombok-one of a dozen across the country-but limited success in recruitment, was in turn interested in having reliable contacts and an entrepreneurial collaborator who would do well in the field, where there was increasing competition for migrants. Having left Lombok since there was no sustainable labour market, Johri returned with his wife and two young children to live in his home village in close proximity to his elderly mother and other relatives.

The PT Timor Tengah office is located about an hour away from Johri's house, in the Mataram residence of Ibu Yuli, a woman in her forties and a distant relative of the Jakarta family that owns the agency. Yuli, who is from Lombok, was unsuccessful during the first few years because she was unable to create a network of PL, largely since she rarely left the office and was too careful with distributing money. Many PL will ask for money to cover initial costs, particularly when recruiting domestic servants, who are increasingly offered money to travel abroad. Previously Yuli refused to do so, correctly believing that there was a risk that she would never see the money or the PL again. Since potential migrants rarely approach agencies without a PL, business remained slow.

Johri's first task upon return to Lombok was therefore to begin to recruit a group of PL, by offering money up front and promising higher fees. He began with acquaintances in and around his home village, but moved into a broader social and geographical realm as his network of connections expanded. These latter connections are generally made outside of recruitment agencies, medical clinics, government agencies such as immigration (where passports are made), all places where PL and migrants spend time hanging out and talking-often under signs warning against brokers (calo) - while waiting for documents to be issued. In order to create a sustainable form of brokerage, PL like Johri eventually need to move beyond their area of residence and work in collaboration with other brokers-or their own sub-brokers-usually individuals living in the same area as the prospective migrants, such as in 
his collaboration with Rina or Pak Haji Ismael's with his son-in-law, the police officer. As there are obvious differences between dialects across the island, Johri is clearly identified as an outsider in large parts of East and North Lombok. He is thus dependant on local sub-brokers such as Rina, and is constantly engaged in attempts to create various forms of strategic partnerships.

Not all Johri's PL have been as reliable as Rina, with some promising migrants but in the end offering them to other PL or agencies. Johri knows that Rina, like his other sub-brokers, may at some point decide to do the same. This is not something they talk about, but he expects it to happen sooner or later. Nor is Johri faithful to PT Timor Tengah, as he often delivers prospective migrants to other agencies, particularly when they want to travel to a country other than Saudi Arabia. Ibu Yuli and the head office in Jakarta are certainly aware of this, since it is common practice, but as long as he continues to deliver there are no complaints. On my latest visit to Lombok in 2010, however, Johri had stopped working with PT Timor Tengah-disappointed by the amount of money he was being paid-and was instead delivering migrants directly to another agency in Jakarta, thereby bypassing the branch office on Lombok. Even though he was making more money he complained that the travelling was taking a toll on him and that there were too many risks involved in recruiting women. Instead he was contemplating opening his own branch recruitment office in Mataram.

\section{Mediating Migration}

For PL like Pak Haji Ismael, Johri and Rina, it is potentially far more lucrative to recruit migrants, particularly female domestic servants, than it is to become a migrant oneself. While male migrants must pay around four million rupiah (US\$400) to work on a palm oil plantation and then are paid at least US\$235 per month during a two-year contract, female domestic servants in Saudi Arabia make US\$215 per month with no deductions. ${ }^{26}$ A PL, however, can make 300,000 rupiah, or US $\$ 30$, for each palm oil migrant delivered, and more than 15 times as much, US $\$ 500$, for each female domestic servant, as fees for the latter have increased dramatically in recent years, most likely as an effect of the global competition for domestic servants. In stark contrast, unskilled day labourers on Lombok make US\$1 to US $\$ 2$ per day.

In the context of the Malaysian palm oil industry, for instance, recruitment agencies are offered job orders for, say, 100 workers to a named plantation in the district of Segamat, a few hours drive from

\footnotetext{
26 This is in contrast to Malaysia and Singapore, where around six months salary can be deducted for fees.
} 
Johor at the border to Singapore, which agencies have a fixed amount of time to fill, usually three months. The actual job order with wages will be photocopied, which the PL shows or distributes to prospective migrants. Most often the group of migrants will depart on the same day, a great logistical feat that involves a large number of PL who deliver the migrants to the agency for government-regulated compulsory pre-departure training a few days before departure. With regard to labour recruitment to Saudi Arabia, different regulations apply and all migrants must pass through agencies in Jakarta, where the passport is produced and predeparture training takes place. This means that the PL either delivers migrants to branch offices on Lombok or travels directly with them to Jakarta, either by plane or bus, depending on the price of available airline tickets. This reflects more general differences between the Middle East and Asia Pacific migration systems-in terms of visa regulations, for instance-as well as politically motivated attempts to control the flow of migrants from Indonesia to Saudi Arabia and more specifically to keep Chinese interests from taking control of the migration industry to the Holy Land. ${ }^{27}$

When it comes to the actual recruitment process the initial stage of contact is of great interest and it is striking to see the different kinds of strategies that PL develop and employ. Female PL such as Rina who focus on the market for domestic servants in Saudi Arabia, for instance, often dress in a Saudi style, while most of the successful older male PL wear the white cap that signals their Haji status. Having been a migrant oneself, preferrably several times, and thus being able to speak competently about the migrant experience is of importance, unless this cannot be compensated for in other ways, as in the case of Haji Ismael, who is a religious authority and widely respected. Other PL develop idiosyncratic styles. For instance, one man who had spent his youth performing a traditional Malay form of theatre used his skills in speaking Malay dialect with migrants, although he had never been to Malaysia himself. Performing various forms of competences, either through speech or dress, thus appears critical beyond the broker mantra: "harus jujur" (you have to be honest). As will be described in some detail below, however, what PL generally share is a social position that allows for mediation between the migrant and the recruitment agencies and government offices, which are the gateways for contemporary migration.

Once a PL and prospective migrant have agreed to proceed, a process of documentation is initiated in order to apply for a special migrant

\footnotetext{
27 On the differences between these migrations systems, see Jon Goss and Bruce Lindquist, "Placing Movers: An Overview of the Asian-Pacific Migration System," The Contemporary Pacific 12, no. 12 (2000): 385-414. The claims about Chinese interests in migration to Saudi Arabia were made in three separate interviews with managers of private recruitment agencies in Jakarta during August 2010.
} 
passport. ${ }^{28}$ At this point, the migrant usually has no contact with the recruitment agency and the PL transports the migrant to and from the different government offices. For the prospective migrant, it would be an arduous and expensive process to gain access to all of the necessary documents on his or her own, and it is therefore nearly impossible not to use a PL, even for migrants who have previously been PL themselves and thus understand the process. If a prospective migrant were to turn directly to the agency, in fact, he or she would be asked to access those documents by way of a PL, or someone within the office would act as the broker at the same charge.

To become a PL one must have a particular kind of social competence that allows for the navigation of government offices, spaces that make most prospective migrants uncomfortable. For both Johri and Pak Haji Ismael, it took time before they began to clearly grasp the proper ways to engage with each government office. In each setting there is a certain amount of money that needs to be included among the paperwork so that the file does not end up in a permanent position at the bottom of the pile, while there may be further idiosyncracies that depend on the particular bureaucrats. Importantly, the fixed amount is not something that one learns by speaking directly with an official, but rather from other brokers who wait outside of the office.

As indicated, there is a clear gendered dimension in the recruitment process, largely because of the high fees offered for female migrants and the fact that domestic servants generally pay off their debt through monthly salary deductions upon arrival in the destination country-the exception being Saudi Arabia-while men must pay prior to departure. ${ }^{29}$ For this reason, PL often offer prospective domestic servants and their husband or parents "shopping money." Generally these gifts are extended in a step-by-step fashion, so as to minimize risk-since there may be other PL with similar offerings-but also to slowly establish a relationship. A gift of money may be followed, for instance, by a trip to the clinic for the medical certificate, thus setting the process in motion before the next sum of money is offered. For men, the PL's main problem is finding prospective migrants who can access capital; payment is therefore usually incremental. In fact, often PL themselves will lend money to male migrants in order to ensure departure. In this process there are risks since it is not always possible to enforce repayment, something that leads many brokers to drop out as they end up in debt. Increasingly, however, contracts are drawn up that involve not only the creditor and the debtor,

28 Most prospective migrants - and indeed most rural inhabitants on Lombok-lack even a birth certificate.

29 Lindquist, "Labour Recruitment." 
but also the village head and debtor's family members. ${ }^{30}$ Usury often looms large, leading most involved-particularly the low-level state officials—-to keep quiet about these issues. As such, while the initial stage of the recruitment process is characterized by performances that aim to create trust, once the recruitment process has reached a point in which major economic investments have been made, there are attempts to formalize the repayment of debt. ${ }^{31}$

Usually PL are engaged in the process of recruitment until departure and are even responsible for transporting the migrant to the recruitment agency as they are about to leave Lombok, or Jakarta, as is the case with those destined for Saudi Arabia. This is actually often the first time the migrant is in direct contact with the agency. If there is a fee to be paid to the PL by the agency, it is usually done right after departure. But even while the migrant is abroad, it is not unusual for the PL to pass on communication or remittances to the migrant's family, particularly if the family lacks a cell phone or a bank account. If the migrant has problems abroad or if the family has not heard from him or her, they usually turn to the PL, who in turn contacts the agency. Often, therefore, the PL retains his or her role as long as the migrant remains abroad.

\section{Situating the Field Agent}

In practice it is often impossible to distinguish formal brokers and informal labour brokers. Unlike the tai kong, the migrant smuggler, or the calo, the middle man, who both connote a shadowy world of illegality, the petugas lapangan, or PL, which is best translated as field agent or assistant, is an explictly bureaucratic term that suggests a hierarchical relationship with the labour recruitment agency. In the government agencies that handle the documentation of migrants there are large signs stating that migrants are not allowed to use calos, while many observers within the labour recruitment industry and the Indonesian government argue that it is critical to regulate petugas lapangan through permits and contracts since they cause problems in the recruitment process, primarily with regard to false claims and promises to migrants. Even some academic observers retain this distinction between the informal calo and formal petugas lapangan, placing blame squarely within the informal sector, while presuming that it is possible to draw a line between the "legal" and "illegal." ${ }^{32}$ In other words, in Indonesia the problem with the current

\footnotetext{
30 Debt can also be reclaimed through the services of paramilitary groups, pamswakarsa, which generally charge 30 percent of the sum returned. From what I can tell, this is primarily used in relationships between agencies and PL, or between PL, rather than in relationships with migrants, who tend to avoid debt through flight.

$31 \quad$ See Lindquist, "Labour Recruitment."

32 Wayne Palmer, "Costly Inducements," Inside Indonesia, no. 100 (2010), http://www. insideindonesia.org/edition-100/costly-inducements-24041289, accessed August 15, 2010.
} 
migration industry is generally identified in relation to the lack of regulation of brokers, a familiar argument in the history of migration. ${ }^{33}$

Once one takes a closer look at the actual recruitment process, however, any distinction between the formal and informal broker becomes problematic, and often even the relationship between the recruitment agency and the informal broker is difficult to sustain. During my research I have not found a single case of a broker who has a contract or even recruits migrants strictly to one recruitment agency. Instead, brokers are paid for each migrant that they successfully deliver to an agency, and will often move migrants from one agency to another if necessary. Managers of recruitment agencies would often claim that PL were the real powerbrokers in the competition for migrants. For the most successful PL, the relationship with the recruitment agency can in some cases even be reversed through a process called pinjam nama, or "name borrowing." PL with direct contacts to plantations in Malaysia, for instance, will in these cases use the agency itself as a broker in order to handle the formal paperwork, but transport the migrants themselves to the employer in Malaysia.

PL vary not only according to occupation, of course, but also in terms of their success in recruiting migrants. A small number of the most successful brokers (together with their own team of sub-brokers) recruit more migrants on their own than most agencies. Pak Haji Said, the most successful PL on Lombok, spent nearly a decade in the 1980s as a labourer and later a foreman (mandor) on a Malaysian palm oil plantation, where he developed relationships with hundreds of migrants across Lombok as well as plantation owners and managers in Malaysia. Based in his home village in East Lombok, Haji Said delivers over one thousand migrants each year to a handful of recruitment agencies. In fact, since agencies depend on their ability to find poweful brokers who have the ability to deliver migrants, they compete for Haji Said's services, generally by offering deductions in fees and guaranteeing job contracts at particular plantations. Today, Haji Said embodies the image of the patron, with large land holdings, a house that doubles as an office, and a team of sub-brokers that recruit migrants from across Lombok and even from neighbouring islands. ${ }^{34}$

Other examples of successful brokers include Pak Din, who spent nearly a decade travelling around Lombok selling farm equipment, before turning to part-time and then finally full-time labour recruitment,

\footnotetext{
33 See, McKeown, this issue.

34 As Boissevain puts it, through Haji Said's control of primary resources, land, capital and people, he has transformed himself from a broker into a patron. See Jeremy Boissevain, Friends of Friends: Networks, Manipulators and Coalitions (Basil Blackwell, 1974), 147-148.
} 
as the one industry came to displace the other. Pak Udin, who works as a researcher at the University of Mataram, the capital of Lombok, was a field researcher for a project dealing with undocumented migration to Malaysia in the 1980s, which resulted in a book on migration from Lombok to Malaysia. In the process, he has used the knowledge he gained from that project to become a successful PL. Finally Ibu Wiwik-the "grandmother" in my title-spent nearly a decade working as a migrant in Saudi Arabia and then at a labour recruitment agency in Jakarta before returning to Lombok to recruit domestic servants full time.

In contrast, many smaller players move in and out of recruitment, either as sub-brokers for more powerful PL or as primary PL, mainly because they lack a sufficient initial investment and thereby opportunity. The typical PL, if there is one, appears to have a relatively steady flow of between 5 to 20 migrants per month, even though there are many more marginal operators who only recruit a handful of migrants before dropping out, as costs come to exceed income. Clearly PL who recruit men to palm oil plantations need a far larger critical mass of migrants, compared to those who recruit domestic servants. Pak Haji Ismael and Johri can be found somewhere in between the typical and most successful brokers, while Rina will need to move beyond the vicinity of her home as it becomes increasingly difficult to find new recruits.

In many ways, however, Pak Haji Ismael is the contemporary norm for the PL. The elementary-school teacher, particularly one who teaches religion, embodies the social position and many of the ethical qualities that are considered critical in the recruitment process. Perhaps somewhat unexpectedly, some of the most successful brokers on Lombok are precisely elementary-school teachers or other low-level bureaucrats, which stands in stark contrast to the image of the labour recruiter as a shadowy, thuggish figure. But this actually makes sense, since the elementary-school teacher is poorly paid, works half-days, is used to speaking in public, is well known and generally trusted across village borders, has literacy with regard to formal documents, and is used to approaching government officials (and, in fact, is one himself). The shift from undocumented to a documented migration, in which the recruitment agency handles the actual transport from Lombok, also means that risks are minimized for the PL, and that responsibility can generally be deferred to the agency if the migrant experiences abuse abroad.

Despite their diverse backgrounds these brokers share a social position-being nearly without exception from the island-that allows them to mediate in cultural terms between villagers and the actors that constitute the migration industry. ${ }^{35}$ But brokers also have a particular kind

35 See Chee, Yeoh, and Vu's article in this issue for a similar discussion of the importance of social position in commercial matchmaking among Malaysian men and Vietnamese migrant women. 
of bureaucratic competence that allows them to engage with government officials and office environments, and a more general experience of urban life, if only the city of Mataram. As such, they are not "traditional," but thoroughly "modern" in their ability to cross various types of boundaries and engage with different types of actors in multiple languages. ${ }^{36}$ Through their cultural and bureaucratic competence, brokers thus become critical gatekeepers for the circulation of migrant labour. ${ }^{37}$

\section{Conclusion}

Recent research suggests that informal migration brokers have been critical to the rise of formal recruitment agencies across Asia, particularly in the context of unskilled labour migration. In Bangladesh, Afsar notes their importance as intermediaries between rural villagers and agencies. These brokers are usually married men-which gives them a particular social legitimacy-with a minimum level of high school education, and personal experience of overseas migration. They generally recruit illiterate migrants in remote villages and help with documents, transport and various forms of translation. In the Philippines, Agunias reports that informal brokers are prevalent in rural areas and generally part of the social network of the migrants they recruit. ${ }^{38}$ In both cases, it is the ruralurban cultural and economic divide, in particular, which accounts for the importance of informal brokers.

These descriptions are in many ways familiar to the Indonesian case. Nevertheless, it is also important to highlight the broader political and economic changes that have led to the increase of informal brokers. As Philip Martin has noted, an unintended consequence of the mutually reinforcing structure of regulation and protection of migrants in Asia

\footnotetext{
36 Again, see the work of Adam McKeown, Melancholy Order, as well as his article in this issue, and Gunther Peck, Reinventing Free Labor, who have both made this point in their historical studies.

37 It is important to compare migrant brokers to the forms of patron-client relationships, which have historically characterized Lombok. As in the 1970s, today the rural poor have only their unskilled labour to sell. Patrons of that era and migrant brokers of the contemporary era both brokered labour, the former through direct hire or exchange, the latter through particular forms of expertise and mediation. Much more could, of course, be written about this. See Mary Judd, "The Sociology of Rural Poverty in Lombok, Indonesia” (PhD dissertation, University of California, Berkeley, 1980).

38 See Rita Afsar, "Unravelling the Vicious Cycle of Recruitment: Labour Migration from Bangladesh to the Gulf States," (Working Paper 63, Geneva: International Labour Office, 2009), 18-19. It is striking to compare with recent studies of the Philippines, Rodriguez, Migrants for Export, and Guevarra, Marketing Dreams, in which the informal broker is hardly mentioned. One important difference, however, is that while these authors focus on skilled nurses, this article is concerned with unskilled migrants. But, see Agunias, "Migration's Middlemen," 8, for a short note on how migrants in rural areas in the Philippines are often approached by brokers.
} 
has been added costs, burdens that migrants themselves have come to carry. ${ }^{39}$ In practice, the current migration regime in Indonesia has quickly evolved in a manner that makes it difficult, if not impossible, for migrants to navigate bureaucracy themselves. Despite the fact that information about the new migration regime is becoming increasingly prevalent, as migrants have easy access to cell phones and move back and forth between, for instance, Malaysian palm oil plantations and rural Lombok, the use of informal brokers remain unavoidable. Necessary during the era of undocumented migration in order to traverse vast geographical spaces and various border-crossings, today brokers are above all experts in the economy and micro-politics of documentationthis within a more constricted space-thus opening up for a new and larger group of entrepreneurs. Many of these brokers would rarely have become migrants themselves or, for that matter, become involved in undocumented migration, but do move easily between government offices and private agencies, as state regulation and market deregulation come to work hand in hand. Pak Haji Ismael, the elementary-school teacher and low-level bureaucrat, comes to function as the perfect intermediary in this world. As in Bestor's telling phrase, these informal brokers are "technicians of globalization" ${ }^{40}$ within the system of circular migration; technicians who do not primarily grasp the broader workings of the system, but, more critically, are able to set the process of migration itself in motion.

Beyond speeding up bureaucratic process, not least through their knowledge of necessary economic transactions in interactions with government officials- jalan tol, or toll road, is a widely used metaphorbrokers also play on particular forms of cultural competence and legitimacy in the villages where they recruit. In contrast to the practical problems of accessing documents, this aspect of brokerage raises issues of trust, highlighted more broadly by Giddens as critical in understanding the consequences of modernity. ${ }^{41}$ In his model of transition, risk in association with a particular type of ontological insecurity stands in stark contrast to fate and a pre-modern sense of security. In the cases I have described above, the prevalence of the cultural broker, one who embodies both local and embedded forms of legitimacy and

\footnotetext{
39 Philip Martin, "Merchants of Labor: Labor Recruiters in Asia," paper presented at the workshop, "Opening the Black Box of Migration: Brokers and the Organization of Transnational Mobility," Asia Research Institute, National University of Singapore, August 19-20, 2010.

40 Theodore Bestor, "Supply-Side Sushi: Commodity, Market, and the Global City," American Anthropologist 103, no. 1 (2001): 76-95.

41 Anthony Giddens, The Consequences of Modernity (Palo Alto: Stanford University Press, 1990).
} 
disembedded knowledge, suggests that there is a space of mediation that remains critical between a local economy of trust and the broader migration system.

For Clifford Geertz-writing about Indonesia 50 years ago-the cultural broker who bridged the divide between the village and the city was bound to disappear as the new nations developed. ${ }^{42}$ The fantasy of development and unmediated communication, shared both in the utopian visions of the early post-colonial and the contemporary neoliberal eras, would seem to lack validity, however, if one considers the current proliferation of brokers. ${ }^{43}$ Although they are often defined as such, individuals such as Pak Haji Ismael, Johri and Rina are not the locus of immorality in this process but, quite the opposite, highly concerned with the security of their recruits, not least because the longterm sustainability of their operation depends on the success of the men and women they deliver to agencies. In fact, the space they inhabit appears likely to endure and raises questions about how trust should be conceptualized in relation to neoliberal and liberal projects or modes of analysis, which either tend to celebrate the "free" migrant or critique this freedom as a mode of governing at a distance. ${ }^{44}$

Stockholm University, Stockholm, Sweden, November 2011

42 This is something that Geertz argued would happen in more general terms in the shift from the bazaar-type to the firm-type economy in East Java in the years before the fall of Sukarno. See Clifford Geertz, Peddlers and Princes: Social Development and Economic Change in Two Indonesian Towns (Chicago: University of Chicago Press, 1963).

$43 \quad$ See Deborah James, "The Return of the Broker: Consensus, Hierarchy, and Choice in South African land reform," Journal of the Royal Anthropological Institute 17, no. 2 (2011): 318-338.

44 On the Foucaultian understanding of "governing at a distance" in the context of labour brokerage, see Anna Guevarra, Marketing Dreams. 